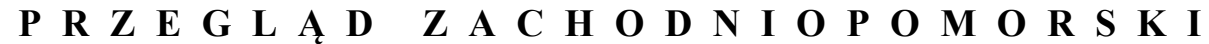 ROCZNIK XXXV (LXIV) ROK 2020 ZESZYT 2
}

\section{$\begin{array}{lllllllll}\mathbf{A} & \mathbf{R} & \mathbf{T} & \mathbf{Y} & \mathbf{K} & \mathbf{U} & \mathbf{L} & \mathbf{Y}\end{array}$}

\author{
ANDRZEJ MYCIO \\ https://orcid.org/0000-0002-2675-2468 \\ Biblioteka Uniwersytecka w Toruniu \\ am@umk.pl
}

\section{RĘKOPISY SZCZECIŃSKIEGO GIMNAZJUM MARIACKIEGO W ZBIORACH BIBLIOTEKI UNIWERSYTECKIEJ W TORUNIU}

Słowa kluczowe: Gimnazjum Mariackie w Szczecinie, Szczecin, Pęzino, Toruń, zbiory zabezpieczone, rękopisy, historia bibliotek

Keywords: Marian Gymnasium in Szczecin, Szczecin, Pęzino, Toruń, restricted collection, manuscripts, history of libraries

Zasób Biblioteki Uniwersyteckiej w Toruniu, która powstała wraz z założeniem Uniwersytetu Mikołaja Kopernika w 1945 roku, w początkowym okresie składał się głównie z tak zwanych zbiorów zabezpieczonych, czyli przede wszystkim książek z byłych niemieckich bibliotek, które po zakończeniu II wojny światowej znalazły się na terenach wcielonych do Polski. W krótkim czasie, w okresie 1945-1949, zgromadzono około 600 tys. woluminów książek, czasopism i jednostek zbiorów specjalnych. Do Torunia zwieziono przede wszystkim książki z terenu byłych Prus Wschodnich oraz dzisiejszego Pomorza Zachodniego. Wśród wskazanych zasobów znalazło się ponad 1000 rękopisów, około 40 tys. starych druków, kilka tysięcy druków muzycznych, około tysiąca map i atlasów, a także mniejsze ilości obiektów graficznych oraz druków ulotnych. Reszta to XIX i XX-wieczne książki i czasopisma ${ }^{1}$.

1 Henryk Baranowski, ,Zbiory Biblioteki Uniwersyteckiej w Toruniu, ich rozwój i kierunki przyszłego kształtowania", w: Studia o działalności i zbiorach Biblioteki Uniwersytetu Mikołaja Kopernika, red. Bogdan Ryszewski, cz. 5 (Toruń: Uniwersytet Mikołaja Kopernika, 1990), 23-27. 
Do dziś przeprowadzono badania proweniencyjne tylko w obrębie kolekcji starych druków ${ }^{2}$ oraz rękopisów ${ }^{3}$. W przypadku pozostałych kolekcji dysponujemy jedynie fragmentarycznymi danymi. Według badań Marii Strutyńskiej, zbiory szczecińskie, w kolekcji starych druków, obejmują w sumie ponad 2 tys. woluminów pochodzących z Biblioteki Miejskiej (Stadtbibliothek Stettin), Generalnej Dyrekcji Ziemstwa Kredytowego (Königliche Preußische Pomersche Generallandschafts Direction), Gimnazjum Miejskiego (Bibliothek des Stadtgymnasiums Stettin) oraz Muzeum Pomorskiego (Pommersches Museum).

W materiałach warsztatowych zgromadzonych przez Marię Strutyńską podczas badań nad strukturą proweniencyjną kolekcji starych druków odnalazłem jeszcze trzy proweniencje, które nie są wymienione w jej książce - są to Zbiorcza Biblioteka Kościelna w Szczecinie (Gesammt-Kirchen Bibliothek zu Stettin), której zbiory w 1908 roku weszły jednak w skład Biblioteki Miejskiej4, Biblioteka Towarzystwa Historii i Starożytności Pomorza w Szczecinie (Bibliothek der Gesellschaft für Pom[mersche] Geschichte u[nd] Alterthumskunde in Stettin) oraz szczecińskie Archiwum Państwowe (König[liche] Staats Archiv zu Stettin) ${ }^{5}$.

Szczecińskie książki dotarły do Torunia dwiema drogami. Jeszcze w 1945 roku Uniwersytet Mikołaja Kopernika otrzymał przydział na zbiory zdeponowane na zamku w Pęzinie koło Stargardu, w którym obok zbiorów Biblioteki Uniwersyteckiej w Griefswaldzie zdeponowano także część zbiorów szczecińskich. Księgozbiór z Pęzina dotarł do Torunia w dwóch transportach - 6 października oraz 2 listopada 1945 roku. Druga droga wiodła bezpośrednio ze Szczecina, w tym wypadku książki do Torunia przyjechały przede wszystkim w następnym, 1946 roku - wtedy zwieziono między innymi duży zbiór nut pochodzący z Biblioteki Miejskiej6. W marcu 1947 roku w Szczecinie zorganizowano zbiornicę książek, z której, już w mniejszych ilościach, ekspediowano książki do Torunia także

2 Maria Strutyńska, Struktura proweniencyjna zbioru starych druków Biblioteki Uniwersyteckiej w Toruniu. Przewodnik po zespołach. Problemy badawcze i metodologiczne (Toruń, 1999).

3 Andrzej Mycio, ,Struktura proweniencyjna rękopisów pochodzących z tak zwanych zbiorów zabezpieczonych w Bibliotece Uniwersyteckiej w Toruniu", Folia Toruniensia 9-10 (2009-2010): $45-55$.

4 Agnieszka Borysowska, Kultura ksiązki w dawnym Szczecinie (XVII-XVIII w.). Studia z pogranicza bibliologii i literaturoznawstwa (Szczecin: Książnica Pomorska, 2018), 349-365.

5 Biblioteka Uniwersytetu Mikołaja Kopernika w Toruniu (dalej: BUMK), archiwum Gabinetu Starych Druków, Materiały warsztatowe Marii Strutyńskiej do tematu struktura proweniencyjna starych druków BUMK; Strutyńska, Struktura, 29-31.

${ }^{6}$ Baranowski, „Zbiory”, 27. 
w końcu lat czterdziestych? Pojedyncze woluminy proweniencji szczecińskiej były kupowane lub nabywane w drodze wymiany również w latach późniejszych ${ }^{8}$.

W Gabinecie Rękopisów Biblioteki Uniwersyteckiej w Toruniu przechowujemy około 1100 jednostek inwentarzowych rękopisów pochodzących ze zbiorów zabezpieczonych. Są to głównie zbiory powstałe w XIX i pierwszej połowie XX wieku, w mniejszym stopniu obiekty starsze (kilkadziesiąt kodeksów średniowiecznych oraz około 250 nowożytnych) ${ }^{9}$. W tym zbiorze znalazły się także kodeksy o proweniencji szczecińskiej. Najliczniejszą grupą manuskryptów szczecińskich są woluminy pochodzące z biblioteki Generalnej Dyrekcji Ziemstwa Kredytowego w Szczecinie. Jest to grupa 27 jednostek inwentarzowych dotyczących historii Pomorza Zachodniego, które wcześniej należały do prywatnych zbiorów historyka Pomorza Ludwiga Wilhelma Brüggemanna (1743-1817), uprzednim właścicielem większości z nich był Christoph Kiel, szczeciński kantor szkoły miejskiej oraz bibliofil i kolekcjoner ${ }^{10}$. Poza tym znajdziemy w tym zbiorze jeden rękopis pochodzący z Biblioteki Miejskiej w Szczecinie ${ }^{11}$ oraz dwie jednostki z Biblioteki Rejencji Szczecińskiej (Hauptbücherei der Regierung Stettin) ${ }^{12}$.

Pozostałe to osiem kodeksów pochodzących ze szczecińskiego Gimnazjum Mariackiego (Marienstifts Gymnasium). Początki tej szkoły sięgają XIII stulecia, w 1543 roku na jej bazie powstało, założone przez książąt pomorskich, Pedagogium, później przemianowane na Gimnazjum Karolińskie oraz Gimnazjum Akademickie. W 1805 roku doszło do połączenia Gimnazjum Akademickiego $\mathrm{z}$ istniejącym od 1404 roku Liceum Miejskim (Ratslyceum), powstało wówczas Królewskie i Miejskie Gimnazjum w Szczecinie (Königliche und Stadt Gymnasium zu Stettin). Jednak już w 1868 roku doszło do ponownego podziału, powstały wówczas: Gimnazjum Miejskie - kontynuator tradycji Liceum Miejskiego oraz Gimnazjum Mariackie - kontynuator tradycji Pedagogium. Umowy regulujące

7 Książnica Pomorska w Szczecinie, archiwum zakładowe, sygn. KP A-5, k. 5; KP A-6, k. 673-709; KP A-8, k. 9-38; KP A-9, k. 328-360; KP A-12, k. 607-617; Borysowska, Kultura, 349-365.

${ }^{8}$ Strutyńska, Struktura, 29.

9 Andrzej Mycio, „Nowożytne rękopisy w zbiorach Biblioteki Uniwersyteckiej w Toruniu”, Czasy Nowożytne 25 (2012): 194; tenże, „Struktura”, 46.

${ }^{10}$ Andrzej Mycio, „Znaczenie kodeksu rękopiśmiennego w XVIII-wiecznej Europie na przykładzie biblioteki historyka Pomorza Ludwiga Wilhelma Brüggemanna”, w: Ksią̇ka i prasa w kulturze, red. Katarzyna Domańska, Bernardeta Iwańska-Cieślik (Bydgoszcz, 2013), 52-69.

${ }^{11}$ BUMK, sygn. Rps 1175/II.

${ }^{12}$ BUMK, sygn. Rps 805/II; Rps 806/I-II; Mycio, „Struktura”, 52-53. Książki z Biblioteki Rejencji Szczecińskiej nie występują w kolekcji starych druków BUMK - patrz przypis 5. 
ponowne rozdzielenie stanowiły, że gros do tej pory wspólnych zbiorów bibliotecznych pozostanie przy Gimnazjum Mariackim ${ }^{13}$.

Siedem, z ośmiu, kodeksów należących do Gimnazjum Mariackiego (na sześciu z nich widnieje pieczęć „Ex Biblioth[eca] Gymn[asii] Pal[eo] Sedin[ensis]”'14) trafiło do Torunia wraz ze zbiorami zabezpieczonymi wkrótce po zakończeniu działań wojennych albo przez Pęzino jeszcze w 1945 roku, albo bezpośrednio ze Szczecina, najpewniej w roku 1946. Ósmy kodeks został natomiast kupiony przez Bibliotekę Uniwersytecką w Toruniu dopiero w 1967 roku. Rękopis ten, przypuszczalnie, po zakończeniu działań wojennych w 1945 roku dostał się w ręce prywatne, w 1967 roku został sprzedany do bydgoskiego antykwariatu i via Bydgoszcz trafił do Torunia.

Analizowaną grupę rękopisów pochodzących z Gimnazjum Mariackiego reprezentują kodeksy z dziedziny prawa, medycyny, teologii oraz bibliotekarstwa. Powstały one od końca XVI do drugiej połowy XVIII wieku. Wydaje się, że najcenniejszy wśród nich jest kodeks zawierający kodyfikację prawa miejskiego obowiązującego w Czechach, którego autorem był Pavel z Koldína ${ }^{15}$ (tekst, napisany w języku czeskim, powstał w 1579 roku ${ }^{16}$. W 1586 roku Friderich Litwin

${ }^{13}$ Stanisław Schwann, wyd., Descriptio Paedagogii Stetinensis 1573. Opis Pedagogium Ksiązęcego w Szczecinie (Szczecin: PWN, 1966), X-XI; Paweł Gut, „Budowa uczelni wyższych w Szczecinie pod koniec XIX i w I połowie XX wieku”, w: Akademicki Szczecin XVI-XXI wiek, red. Piotr Niedzielski, Waldemar Tarczyński (Szczecin: Wydawnictwo Naukowe Uniwersytetu Szczecińskiego, 2016), 82; tenże, „Szczecińskie akademickie szkoły średnie w II połowie XVII i XVIII wieku", w: tamże, 47-80; Janina Kosman, Z dziejów bibliotek w pruskiej prowincji Pomorza w XIX i początkach XX wieku (Szczecin: Książnica Pomorska im. Stanisława Staszica, 2013), 149-150; Zofia Mielcarek, Bolesław Owczarek, Od Pedagogium do Uniwersytetu Szczecińskiego (Szczecin: Wydawnictwo Glob, 1985), 63-70; Martin Wehrmann, „Geschichte der Bibliothek des Marienstifts-Gimnasiums”, Baltische Studien 44 (1894), 220-224; Sylwia Wesołowska, „Zarys dziejów szkolnictwa na Pomorzu i w Szczecinie do połowy XVI w.", w: Od Pedagogium Ksiażęcego do Gimnazjum Mariackiego. $Z$ dziejów szkolnictwa pótwyższego w Szczecinie do początków XIX w., red. Agnieszka Borysowska (Szczecin: Książnica Pomorska im. Stanisława Staszica, 2018), 20-22.

${ }^{14}$ Marta Kurzyńska, „Druki pomorskie w kolekcji starych druków Muzeum Narodowego w Szczecinie na tle zasobów muzeów Pomorza Zachodniego", w: Piśmiennictwo na Pomorzu Zachodnim do końca XVIII wieku, red. Janina Kosman (Szczecin: Wydawnictwo Archiwum Państwowego „Dokument”: Wydział Filologiczny Uniwersytetu Szczecińskiego, 2015), 50.

${ }^{15}$ BUMK, sygn. Rps 165/III, Pavel Kristián Kolda z Koldína (1530-1589), Neue Reformation und corrigirte Stadtrecht des hochberühmsten Königreichs Behems mit sondern uleisz ausz Boheimischer zu teuttzscher Sprach gebracht zu Nätz und Frommen allen Inwohnern bemelter Crohn Behaims so der Behaimischen Sprach unbericht und vor Gericht zu handeln haben id. 1586.

${ }^{16}$ Josef Jireček, wyd., Práva městská království Českého a markrabství Moravského spolu s krátkou jich Summou od Pavla Krystyana z Koldina (Praha: nákladem Spolku českých právníků ,Všehrd', 1876). 
dokonał przekładu tekstu Pavla z Koldína na język niemiecki ${ }^{17}$, wzorował się przy tym na wcześniejszym tłumaczeniu sporządzonym w 1580 roku przez Petra Štěrbę ${ }^{18}$. Szczeciński rękopis jest wczesnym egzemplarzem przekładu Litwina, powstał zapewne jeszcze w XVI stuleciu, czego dowodzi filigran papieru manuskryptu ${ }^{19}$. Tekst został sporządzony pismem kancelaryjnym, oprawa kodeksu wykonana została $z$ tektury obleczonej pergaminem. Na oprawie widnieją ślepe tłoczenia geometryczne, widoczne są również pozostałości po dwóch skórzanych wiązaniach. Dawne sygnatury kodeksu, zapewne związane ze szkolną biblioteką to: „XL,7” oraz „Jur.f.68.”.

Drugi rękopis, również o tematyce prawnej, zawiera słowniczek pojęć z zakresu prawa miejskiego ułożonych alfabetycznie ${ }^{20}$. Powstał $\mathrm{w}$ drugiej połowie XVII stulecia, posiada tekturową oprawę typu kopertowego obleczoną w pergamin. Zachowały się dwie dawne sygnatury: „XXVI,93” oraz „Jur.o.215”. Na karcie I recto znajduje się zapiska proweniencyjna, z której dowiadujemy się, że ów kodeks należał początkowo do studenta prawa Arnolda Blumha ${ }^{21}$, a następnie był własnością Marcusa Detleva Friese (1634-1710), prawnika i radcy na dworze szwedzkim i pruskim, który ostanie lata swojego życia spędził w Szczecinie. Co prawda pod tą zapiską widnieje data 1609 , ale jest to zapewne błąd i chodzi tu o datę 1709. Niewątpliwie bowiem dukt podpisu znajdującego się w zapisce: „D M Frisii” jednoznacznie wiąże go z osobą Marcusa Detleva Friese, który w 1709 roku zapisał swój księgozbiór, głównie książki o tematyce prawniczej i historycznej, w tym rękopisy, bibliotece Gimnazjum Karolińskiego ${ }^{22}$.

\footnotetext{
${ }^{17}$ Georg Lehmann, wyd., Vollständige teutsche Stadt-Recht im Erb-Königreich Böheim und Marggrafthum Mähren, von einem, dem Publico geneigten Rechtsgelehrten in Druck befördert (Wienn: Rungger, 1720).

${ }^{18}$ František Hoffmann, „O překladech a rozšířeni koldínových práv městských”, w: Městské právo v 16.-18. století v Evropě. Sborník př́spévků z mezinárodni konference usporádané právnickou fakultou uk ve dnech 25.-27. záŕi 1979 v Praze, red. Karel Malý (Praha: Univerzita Karlova, 1982), 257, 261; tenże, „Rozšířeni koldínových práv městských v českých, německých a latinských podobách (Ke 400. výroči vydáni Práv městských)", Studie o rukopisech 18 (1979): 61-62.

${ }^{19}$ Charles-Moïse Briquet, Les filigranes. Dictionnaire historique des marques du papier dès leur apparition vers 1282 jusqu'en 1600 (Mansfield Centre, CT: Martino, 2007 - reprint druku z 1907), t. 1, poz. 226.

${ }^{20}$ BUMK, sygn. Rps 318/I.

${ }^{21}$ Arnold Bluhm został odnotowany w bazie Cerl Thesaurus, widnieje w niej jako student na Uniwersytecie w Heidelbergu w 1677 r., dostęp 30.12.2019, https://ata.cerl.org/thesaurus/ cnp00687167.
}

${ }^{22}$ Agnieszka Borysowska, „Biblioteka szczecińskiego Gimnazjum Akademickiego w XVIII w.”, w: Od Pedagogium Ksiązęcego do Gimnazjum Mariackiego. Z dziejów szkolnictwa 
Trzeci manuskrypt reprezentuje także dziedzinę prawa, tym razem jest to kodeks zawierający akademickie wykłady z prawa feudalnego obowiązującego w krajach niemieckich ${ }^{23}$. Rękopis powstał w 1772 roku, został oprawiony w tekturę, posiada sygnatury szkolnej biblioteki - „XXVII,237” oraz „Jur.g.14”. Wykłady prowadzone przez profesora Philippa Ernesta Bertrama (1726-1777) ${ }^{24}$ spisane zostały prawdopodobnie przez jednego z jego studentów - A. Contiusa. Swoje wykłady Bertram oparł na kilka lat wcześniej wydanym podręczniku, którego autorem był Georg Ludwig Böhmer (1715[1717?]-1797) ${ }^{25}$ „Pricipia juris feudalis praesertim Longobardici quod per Germaniam obtinet" ${ }^{26}$. Manuskrypt powstał na Uniwersytecie w Halle jeszcze w czasie, gdy Bertram prowadził tam wykłady. Świadczy o tym zapis na stronie tytułowej „Halle den 5ten May 1772”, jak i filigran papieru opisywanego kodeksu, który wiąże go z papiernią w Halle ${ }^{27}$. Rękopis ten był z pewnością początkowo wykorzystywany przez samego A. Contiusa, a później być może także i innych studentów prawa Uniwersytetu w Halle jako skrypt akademicki. Następnie trafił do zbiorów szczecińskiego Gimnazjum Mariackiego bezpośrednio albo przez bibliotekę Liceum Miejskiego.

Drugą grupę tematyczną tworzą manuskrypty medyczne. Są to trzy kodeksy ${ }^{28}$, które pierwotnie należały do szczecińskiego lekarza i poety Andreasa Hiltebranda (1581-1637). Powstały w latach 1603-1605 w Lejdzie, w której Hiltebrand studiował. Zawierają przede wszystkim wypisy z różnego rodzaju dzieł i podręczników medycznych przydatnych w czasie studiowania oraz zbiory tez

półwyższego w Szczecinie do początków XIX w., red. taż (Szczecin: Książnica Pomorska im. Stanisława Staszica, 2018), 146-154; Borysowska, Kultura, 349-365; Agata Michalska, „Detlev Marcus Friese", w: Encyklopedia Pomorza Zachodniego, dostęp 27.12.2019, http://www.pomeranica. pl/wiki/Detlev_Marcus_Friese.

${ }^{23}$ BUMK, sygn. Rps 236/II, Bemerkungen aus des Philipp Ernst Bertrams (1726-1777) Vorlesungen über Georg Ludwig Böhmer (1715[1717?]-1797) „Pricipia juris feudalis praesertim Longobardici quod per Germaniam obtinet" gesammelt von A. Contius.

${ }^{24}$ Ernst Kelchner, „Bertram Philipp Ernst”, w: Allgemeine Deutsche Biographie, t. 2 (Berlin: Duncker \& Humblot, 1967, reprint wyd. z 1875), 551.

${ }^{25}$ Richard W. Dove, „Böhmer Georg Ludwig”, w: tamże, t. 3 (Berlin: Duncker \& Humblot, 1967, reprint wyd. z 1876), 73-74; Hans Liermann, „Böhmer Georg Ludwig”, w: Neue Deutsche Biographie, t. 2 (Berlin: Duncker \& Humblot, 1955), 391.

${ }^{26}$ Pierwsze wydanie: Gottingae: Vandenhoeck, 1765.

${ }^{27} \mathrm{Na}$ znaku wodnym widnieje napis: „Halle”.

${ }^{28}$ BUMK, sygn. Rps 105/I; 106/I; 215/I. Ostatni z wymienionych kodeksów nie został oznakowany pieczęcią Gimnazjum Mariackiego, jednak sygnatury na oprawie i na wyklejce górnej okładziny jednoznacznie wiążą go z dwoma pozostałymi woluminami. 
panujących w owym czasie w medycynie ${ }^{29}$. Sporządzono je w języku łacińskim, a fragmenty także $\mathrm{w}$ języku greckim. Woluminy oprawione są w pergamin, wszystkie posiadają rejestry introligatorskie. Jeden z woluminów został opatrzony w dwa wiązania na tasiemkę $e^{30}$, drugi ma pozostałości po identycznych wiązaniach $^{31}$. Zachowały się dawne sygnatury: „366”; „367”, „368”; „Med.q.27(1)”; „Med.q.27(2)”; „19”; „43”; „VI.gr”, które zapewne należy wiązać z gimnazjalną biblioteką. Jeden $\mathrm{z}$ tych trzech kodeksów ${ }^{32}$ zainteresował ostatnio badaczy, bowiem oprócz ekscerptów z podręczników medycznych zawiera także protokół z zebrania - dysputy nad problemami z zakresu fizjologii i patologii, która miała miejsce latem 1604 roku w Lejdzie. Wzmiankowane kolegium odbyło się w domu Pietera Pauw (1564-1617), niderlandzkiego lekarza, anatoma i botanika, profesora nauk medycznych Uniwersytetu w Lejdzie. Andreas Hiltebrand brał w tym kolegium czynny udział i sporządził protokół z tego spotkania ${ }^{33}$.

Hiltebrand jeszcze $\mathrm{w}$ okresie młodzieńczym pobierał nauki w szczecińskim Liceum Miejskim, w ostatnich latach swojego życia był związany z Pedagogium Książęcym. Wydaje się, że swój księgozbiór przekazał raczej do Liceum Miejskiego (w 1677 roku podczas oblężenia Szczecina przez wojska brandenburskie spłonęło Pedagogium wraz z biblioteką). Jego rękopisy stały się później częścią połączonej biblioteki Królewskiego i Miejskiego Gimnazjum w Szczecinie, a po 1868 roku trafiły do zasobów Gimnazjum Mariackiego ${ }^{34}$.

Siódmy kodeks $\mathrm{z}$ grupy analizowanych manuskryptów, zatytułowany Einleitung in die Heilige Schriftit ${ }^{35}$, reprezentuje teologię. Rękopis (sporządzony kursywą w drugiej połowie XVIII wieku) zawiera blisko 500 stron tekstu w języku niemieckim (fragmenty w językach łacińskim oraz greckim), oprawione w tekturę. Autorem tekstu, który ma charakter skryptu akademickiego, jest

${ }^{29}$ Ulrich Schlegelmilch, ,Andreas Hiltebrands Protokoll eines Disputationscollegiums zur Physiologie und Pathologie (Leiden 1604)", w: Frühneuzeitliche Disputationen. Polyvalente Produktionsapparate gelehrten Wissens, red. Marion Gindhart, Hanspeter Marti, Robert Seidel, przy współpr. Karin Marti-Weissenbach (Köln-Weimar-Wien: Böhlau Verlag, 2016), 51-54.

${ }^{30}$ BUMK, sygn. Rps 105/I.

${ }^{31}$ BUMK, sygn. Rps 106/I.

${ }^{32}$ BUMK, sygn. Rps 105/I.

${ }^{33}$ Schlegelmilch, ,Andreas”, 54-88.

${ }^{34}$ Achim Aurnhammer, ,Andreas Hiltebrand - ein pommerscher Dichterarzt zwischen Späthumanismus und Frühbarock", w: Pommern in der Frühen Neuzeit. Literatur und Kultur in Stadt und Region, red. Wilhelm Kühlmann, Horst Langer (Tübingen: Max Niemeyer, 1994), 202, 206-207; Borysowska, ,Biblioteka”, 63-70.

${ }^{35}$ BUMK, sygn. Rps 242/II. 
najprawdopodobniej jeden z lokalnych, związanych ze Szczecinem, teologów. Filigrany papieru kodeksu wskazują na papiernię w stosunkowo nieodległym Magdeburgu. Wolumin oznaczono sygnaturami podobnymi do sygnatur wcześniej opisywanych kodeksów, a mianowicie: „XXII, 205” oraz „Th.E.IV.q.17”. Ostatecznie kodeks ten trafił do Biblioteki Gimnazjum Mariackiego albo bezpośrednio, albo poprzez bibliotekę Liceum Miejskiego, podobnie jak wzmiankowany wyżej skrypt z prawa feudalnego.

Ostatni z analizowanych kodeksów ${ }^{36}$ powstał w 1768 roku, zawiera ponad 600 stron (oprawionych w tekturę) spisanych głównie w językach niemieckim oraz łacińskim. Ówczesny profesor szczecińskiego Gimnazjum Akademickiego Johann Carl Conrad Oelrichs (1722-1799) odnalazł w małej skrzyni, znajdującej się w Bibliotece Gimnazjum, dokumenty, głównie katalogi, inwentarze i wykazy darów i zlecił ich zszycie w jeden wolumin. Wszystkie zebrane dokumenty, włącznie z najstarszym - katalogiem książek z 1590 roku (znak wodny potwierdza datację dokumentu) oraz inwentarzem rękopisów, wydatowanym na podstawie filigranu papieru na przełom XVI i XVII wieku, znajdowały się zapewne od czasu swojego powstania do momentu zszycia woluminu w pomieszczeniach biblioteki. Sto lat później - w 1873 roku - ówczesny bibliotekarz Hugo Lemcke spaginował manuskrypt i sporządził spis zawartości. Kodeks zawiera także późniejsze (z 1894 r.), drobne zapiski na temat doklejenia kart (I oraz 366a-b), naniesione przez Martina Wehrmanna, nauczyciela i bibliotekarza Gimnazjum. Zapewne także on naniósł paginację na kartach: 366a-b oraz 438a-b i dokleił także do woluminu karty: I-II oraz 366a-b i 438a-b. Wolumin był niewątpliwie przechowywany w Bibliotece Gimnazjum do II wojny światowej ${ }^{37}$.

${ }^{36}$ BUMK, sygn. Rps 1148/IV, Johann Carl Conrad Oelrichs, Haec, orginem atque incrementa bibliothecae aedis cathedralis Marianae regii que Gymnasi Academici, spectantia authentica documenta, post temporis spatium satis longum eheu neglecta, in fundatorum Balduini, Mülleri, Frisii, aliorumque memoriam, a pulueris magna vi purgata, colligere, atque simul hos historiae bibliothecae huius publicae fontes, una cum reperto ibidem, hac occasione, IV libros flori historiar. Romanor. nitidiss. codice membranae saec. XIV. aut ineuntis XV in lucem revocare, eosque colligando ab interitu vindicare, e re fore duxit $\%$..

${ }^{37}$ Borysowska, Kultura, 349-365; Briquet, Les filigranes, t. 1, poz. 120 (wariant); Johann Carl Conrad Oelrichs, Fortgesetzte historisch-diplomatische Beyträge zur Geschichte der Gelahrtheit besonders im Herzogthum Pommern (Berlin: in Commiszion der Real-Schule Buchhandlung, 1770), 187-192; Gerhard Piccard, Wasserzeichenkartei, t. 15, cz. 1 (Stuttgart: Verlag W. Kohlhammer, 1987), poz. 902 (wariant); Wasserzeichen-Informationssystem, Referenznummer DE4620-PO-123217 - wariant, dostęp 17.12.2019, https://www.wasserzeichen-online.de; Martin Wehrmann, „Geschichte des Königlichen Marienstifts-Gymnasiums (des früheren Herzoglichen Pädagogiums und Königl. akademischen Gymnasiums) in Stettin 1544-1894”, w: Festschrift zum dreihundertfünfzigjährigen Jubiläum des Königlichen Marienstifts-Gymnasiums zu Stettin um 24. 
W toruńskiej książnicy uniwersyteckiej przechowujemy dziś tylko niewielki fragment rękopiśmiennych zbiorów szczecińskiego Gimnazjum Mariackiego, to zaledwie osiem woluminów. Są to jednak obiekty cenne, bo pochodzące z odległej już w czasie epoki nowożytnej (XVI-XVIII w.). Siedem pierwszych reprezentuje dziedziny, którymi nauka w owym czasie była najbardziej zainteresowana, a mianowicie: teologię, prawo i medycynę. Ich zawartość odzwierciedla stan ówczesnej myśli i jest doskonałym materiałem źródłowym do badań w zakresie historii nauki. Ósmy zawiera biblioteczne katalogi i inwentarze, reprezentuje więc dziedzinę bibliotekarstwa i jest niezwykle cenny dla dzisiejszych bibliologów, pozwala bowiem na wgląd w strukturę historycznych zbiorów bibliotecznych, które do dziś nie przetrwały w całości; analiza takich kodeksów daje możliwości stawiania nowych tez naukowych. Trudno określić ile książek szczecińskiego Gimnazjum Mariackiego dotarło w ogóle do Torunia, niestety nie dysponujemy w tym przypadku pełnymi danymi, ciągle brak obszernych badań proweniencyjnych. Na podstawie badań przeprowadzonych przez Marię Strutyńską ${ }^{38}$ książek tej proweniencji nie ma w ogóle wśród przechowywanych w Toruniu starych druków. Być może jakaś część zbiorów Gimnazjum Mariackiego znajduje się w zbiorze książek nowych przechowywanych w Bibliotece Uniwersyteckiej w Toruniu lub w zbiorze druków muzycznych, tu jednak wciąż brak nam szeroko zakrojonych badań proweniencyjnych.

\section{Bibliografia}

\section{Źródła}

Biblioteka Uniwersytecka w Toruniu. Archiwum Gabinetu Starych Druków, Materiały warsztatowe Marii Strutyńskiej do tematu struktura proweniencyjna starych druków Biblioteki Uniwersytetu Mikołaja Kopernika, bez sygnatury.

Biblioteka Uniwersytecka w Toruniu, sygn. Rps 105/I; 106/I; 165/III; 215/I; 236/II; 242/ II; 318/I; 805/II; 806/I-II; 1148/IV; 1175/II.

Jireček, Josef, wyd. Práva městská královstvi Českého a markrabstvi Moravského spolu s krátkou jich Summou od Pavla Krystyana z Koldina. Praha: nákladem Spolku českých právníků, Všehrd', 1876.

Książnica Pomorska w Szczecinie, archiwum zakładowe, sygn. KP A-5; KP A-6; KP A-8; KP A-9; KP A-12.

und 25. September 1894 (Stettin: Herrcke \& Lebeling, 1894), 59, 61, 92, 122, 176; Martin Wehrmann, „Geschichte der Bibliothek des Marienstifts-Gimnasiums”, Baltische Studien 44 (1894): 206-210, 225-226.

${ }^{38}$ Strutyńska, Struktura, 29. 
Lehmann, Georg, wyd. Vollständige teutsche Stadt-Recht im Erb-Königreich Böheim und Marggrafthum Mähren, von einem, dem Publico geneigten Rechtsgelehrten in Druck befördert. Wienn: Rungger, 1720.

Schwann, Stanisław, wyd. Descriptio Paedagogii Stetinensis 1573. Opis Pedagogium Książęcego w Szczecinie. Szczecin: PWN, 1966.

\section{Opracowania}

Aurnhammer, Achim. „Andreas Hiltebrand - ein pommerscher Dichterarzt zwischen Späthumanismus und Frühbarock”. W: Pommern in der Frühen Neuzeit. Literatur und Kultur in Stadt und Region, red. Wilhelm Kühlmann, Horst Langer, 199-225. Tübingen: Max Niemeyer, 1994.

Baranowski, Henryk. „Zbiory Biblioteki Uniwersyteckiej w Toruniu, ich rozwój i kierunki przyszłego kształtowania”. W: Studia o działalności i zbiorach Biblioteki Uniwersytetu Mikołaja Kopernika, red. Bogdan Ryszewski, 21-45. Cz. 5. Toruń: Uniwersytet Mikołaja Kopernika, 1990.

Böhmer, Georg Ludwig. Pricipia juris feudalis praesertim Longobardici quod per Germaniam obtinet. Gottingae: Vandenhoeck, 1765.

Borysowska, Agnieszka. „Biblioteka szczecińskiego Gimnazjum Akademickiego w XVIII w.”. W: Od Pedagogium Książęcego do Gimnazjum Mariackiego. Z dziejów szkolnictwa półwyższego w Szczecinie do początków XIX w., red. Agnieszka Borysowska, 145-158. Szczecin: Książnica Pomorska im. Stanisława Staszica, 2018.

Borysowska, Agnieszka. Kultura książki w dawnym Szczecinie (XVII-XVIII w.). Studia z pogranicza bibliologii i literaturoznawstwa. Szczecin: Książnica Pomorska im. Stanisława Staszica, 2018.

Briquet, Charles-Moïse. Les filigranes. Dictionnaire historique des marques du papier dès leur apparition vers 1282 jusqu'en 1600. Mansfield Centre, CT: Martino, 2007 (reprint druku z 1907).

Dove, Richard W. „Böhmer Georg Ludwig”. W: Allgemeine Deutsche Biographie, 73-74. T. 3. Berlin: Duncker \& Humblot, 1967 (reprint wyd. z 1876).

Gut, Paweł. „Budowa uczelni wyższych w Szczecinie pod koniec XIX i w I połowie XX wieku". W: Akademicki Szczecin XVI-XXI wiek, red. Piotr Niedzielski, Waldemar Tarczyński, 81-106. Szczecin: Wydawnictwo Naukowe Uniwersytetu Szczecińskiego, 2016.

Gut, Paweł. „Szczecińskie akademickie szkoły średnie w II połowie XVII i XVIII wieku”. W: Akademicki Szczecin XVI-XXI wiek, red. Piotr Niedzielski, Waldemar Tarczyński, 47-80. Szczecin: Wydawnictwo Naukowe Uniwersytetu Szczecińskiego, 2016.

Hoffmann, František. „O překladech a rozšířeni koldínových práv městských”. W: Městské právo v 16.-18. století v Evropě. Sborník př́spévků z mezinárodni konference 
uspořádané právnickou fakultou uk ve dnech 25.-27. záři 1979 v Praze, red. Karel Malý, 257-266. Praha: Univerzita Karlova, 1982.

Hoffmann, František. „Rozšířreni koldínových práv městských v českých, německých a latinských podobách (Ke 400. výroči vydáni Práv městských)”. Studie o rukopisech 18 (1979): 61-62.

Kelchner, Ernst. „Bertram Philipp Ernst”. W: Allgemeine Deutsche Biographie, red. Historische Commission bei der Königl. Akademie der Wissenschaften, 551. T. 2. Berlin: Duncker \& Humblot, 1967 (reprint wyd. z 1875).

Kosman, Janina. Z dziejów bibliotek $w$ pruskiej prowincji Pomorza w XIX i poczatkach XX wieku. Szczecin: Książnica Pomorska im. Stanisława Staszica, 2013.

Kurzyńska, Marta. „Druki pomorskie w kolekcji starych druków Muzeum Narodowego w Szczecinie na tle zasobów muzeów Pomorza Zachodniego". W: Piśmiennictwo na Pomorzu Zachodnim do końca XVIII wieku, red. Janina Kosman, 33-54. Szczecin: Wydawnictwo Archiwum Państwowego „Dokument” - Wydział Filologiczny Uniwersytetu Szczecińskiego, 2015.

Liermann, Hans. „Böhmer Georg Ludwig”. W: Neue Deutsche Biographie, red. Historischen Kommission bei der Bayerischen Akademie der Wissenschaften, 391. T. 2. Berlin: Duncker \& Humblot, 1955.

Michalska, Agata. „Detlev Marcus Friese”. W: Encyklopedia Pomorza Zachodniego. Dostęp 27.12.2019. http://www.pomeranica.pl/wiki/Detlev_Marcus_Friese.

Mielcarek, Zofia, Bolesław Owczarek. Od Pedagogium do Uniwersytetu Szczecińskiego. Szczecin: Wydawnictwo Glob, 1985.

Mycio, Andrzej. „Nowożytne rękopisy w zbiorach Biblioteki Uniwersyteckiej w Toruniu”. Czasy Nowożytne 25 (2012): 193-205.

Mycio, Andrzej. „Struktura proweniencyjna rękopisów pochodzących z tak zwanych zbiorów zabezpieczonych w Bibliotece Uniwersyteckiej w Toruniu". Folia Toruniensia 9-10 (2009-2010): 45-55.

Mycio, Andrzej. „Znaczenie kodeksu rękopiśmiennego w XVIII-wiecznej Europie na przykładzie biblioteki historyka Pomorza Ludwiga Wilhelma Brüggemanna". W: Książa i prasa w kulturze, red. Katarzyna Domańska, Bernardeta Iwańska-Cieślik, 52-69. Bydgoszcz, 2013.

Oelrichs, Johann Carl Conrad. Fortgesetzte historisch-diplomatische Beyträge zur Geschichte der Gelahrtheit besonders im Herzogthum Pommern. Berlin: in Commiszion der Real-Schule Buchhandlung, 1770.

Piccard, Gerhard. Wasserzeichenkartei. T. 15: cz. 1. Stuttgart: Verlag W. Kohlhammer, 1987. 
Schlegelmilch, Ulrich. „Andreas Hiltebrands Protokoll eines Disputationscollegiums zur Physiologie und Pathologie (Leiden 1604)”. W: Frühneuzeitliche Disputationen. Polyvalente Produktionsapparate gelehrten Wissens, red. Marion Gindhart, Marti Hanspeter, Robert Seidel, przy współpr. Karin Marti-Weissenbach, 49-88. Köln-Weimar-Wien: Böhlau Verlag, 2016.

Strutyńska, Maria. Struktura proweniencyjna zbioru starych druków Biblioteki Uniwersyteckiej w Toruniu. Przewodnik po zespołach. Problemy badawcze $i$ metodologiczne. Toruń, 1999.

Wasserzeichen-Informationssystem. Dostęp 17.12.2019. https://www.wasserzeichen-online.de.

Wehrmann, Martin. „Geschichte der Bibliothek des Marienstifts-Gimnasiums”. Baltische Studien 44 (1894): 195-226.

Wehrmann, Martin. „Geschichte des Königlichen Marienstifts-Gymnasiums (des früheren Herzoglichen Pädagogiums und Königl. akademischen Gymnasiums) in Stettin 1544-1894". W: Festschrift zum dreihundertfünfzigjährigen Jubiläum des Königlichen Marienstifts-Gymnasiums zu Stettin um 24. und 25. September 1894, 1-165. Stettin: Herrcke \& Lebeling, 1894.

Wesołowska, Sylwia. „Zarys dziejów szkolnictwa na Pomorzu i w Szczecinie do połowy XVI w.". W: Od Pedagogium Książęcego do Gimnazjum Mariackiego. Z dziejów szkolnictwa półwyższego w Szczecinie do początków XIX w., red. Agnieszka Borysowska, 11-22. Szczecin: Książnica Pomorska im. Stanisława Staszica, 2018.

\begin{abstract}
Abstrakt
Zbiory zabytkowe Biblioteki Uniwersyteckiej w Toruniu, w swoim podstawowym zrębie, zostały ukształtowane po zakończeniu II wojny światowej na bazie tak zwanych zbiorów zabezpieczonych, czyli przede wszystkim książek pochodzących z byłych niemieckich bibliotek. Do Torunia trafiły głównie książki z Prus Wschodnich oraz Pomorza. Niemała część zbiorów poniemieckich pochodzi ze Szczecina, w tym także książki przechowywane do II wojny światowej w Bibliotece Gimnazjum Mariackiego, kontynuatora tradycji Pedagogium Książęcego. Szczecińskie zbiory trafiły do Torunia krótko po zakończeniu działań II wojny światowej albo bezpośrednio ze Szczecina, albo via Pęzino, dokąd zostały ewakuowane przez administrację niemiecką w celu ich ochrony przed alianckimi bombardowaniami. Pojedyncze książki szczecińskiej proweniencji były nabywane przez Bibliotekę Uniwersytecką w Toruniu także w latach późniejszych. W toruńskiej książnicy uniwersyteckiej przechowujemy dziś osiem kodeksów rękopiśmiennych pochodzących z Biblioteki Gimnazjum Mariackiego w Szczecinie. Wszystkie manuskrypty powstały w okresie nowożytnym, od końca XVI do II połowy XVIII w. Siedem pierwszych reprezentuje dziedziny: prawa, medycyny oraz teologii - ich zawartość odzwierciedla
\end{abstract}


stan ówczesnej myśli i jest doskonałym materiałem źródłowym do badań w zakresie historii nauki. Ósmy zawiera biblioteczne katalogi i inwentarze, z tego względu jest szczególnie cenny dla badaczy historii szczecińskiego Gimnazjum oraz jego Biblioteki.

\title{
Manuscripts of the Szczecin Marian Gymnasium IN THE COLLECTION OF THE UNIVERSITY LibRARY IN TORUŃ
}

\begin{abstract}
The historic collection of the University Library in Torun in its fundamental shape was formed after the World War II, based on the so called restricted collection, i.e. primarily the books from the former German libraries. To Torun came mainly books from Eastern Prussia and Pomerania. Substantial part of the post-German collection came from Szczecin, including the books kept until the World War II in the Library of the Marian Gymnasium, which continued the tradition of the princely Pedagogium. The Szczecin collection came to Torun shortly after the military operations of the Wold War II came to an end, either directly from Szczecin or via Pęzino, where they were evacuated by the German administration in order to protect them from the Allied bombings. Single books of Szczecin provenience were bought by the University Library in Torun also in the subsequent years. In the Torun university library we house today eight manuscript codices from the Marian Gymnasium Library in Szczecin. All the manuscripts came into being in the modern period, from the late $16^{\text {th }}$ century until second half of the $18^{\text {th }}$ century. Seven of them represent the domains of law, medicine, and theology. Their content reflects the then state of thought and is a perfect source material for studies into the history of science. The eighth one contains the library catalogues and inventories, and is particularly precious for the researchers of history of the Szczecin Gymnasium and its Library.
\end{abstract}

